\title{
CITRA KOMUNIS AMBIVALEN \& IDE-IDE ISLAM MODERNIS (Tinjauan atas Roman-Roman Abdoe'l Xarim M.S. sebelum Perang)
}

\author{
Dedi Arsa \\ (Budayawan. Email: deddyarsya1987@gmail.com)
}

\begin{abstract}
Abdoe'lxarim M.S. menempati posisi tersendiri dalam sejarah kesusastraan sebelum perang. Dia pengarang roman yang cukup produktif; salah satu aktivis komunis Sumatra yang utama sebelum dan sesudah perang; dan sekaligus pendukung ide-ide kaum modernis Islam. Artikel ini menelaah dua romannya yang terpenting, Pandoe Anak Boeangan dan Hadji Dadjal.Dengan menggunakan pendekatan neo-historisisme, artikel ini melihat pandangan-pandangan apa yang hendak diusung kedua roman itu sertabagaimana keterkaitannya dengan realitas-biografis pengarangnya. Dari hasil pengkajian ditemukan bahwa roman pertama merepresentasikan citra komunis yang ambivalen; roman kedua menggemakan ide-ide kaum modernis-Islam;kedua roman itu paralel atau berkait dengan kondisi sosial zaman dan realitas-biografis Abdoe'l xarim.
\end{abstract}

Kata Kunci: Roman, Citra, Modernis.

\section{PENDAHULUAN}

Abdoe'l xarim M.S. adalah sosok yang unik, dia aktivis pergerakan sekaligus pengarang roman. Dalam gerakan politik dia tercatat sebagai elite penting partai komunis sebelum dan sesudah masa perang, tetapi dia juga menjalin hubungan yang erat dengan kalangan Islam modernis. Sebagai pengarang, roman-romannya merepresentasikan kedua kutub tersebut. Dua kutub yang lebih sering [nyaris selalu] berseberangan. Tetapi di tangan Xarim keduanya kadang dapat dipadukan melalui karya sastra [roman-roman] yang ditulisnya.

Artikel ini menelaah bagaimana pandangan Xarim tentang ide-ide kaum komunis dan Islammodernis?; serta bagaimana pandangan-pandangan tersebut berkait dengan realitas-biografis Xarim [pengarang] sendiri? Rujukan utama yang ditelaah adalah dua roman karya Xarim yang terpenting: Pandoe Anak Boeangan (1933) dan Hadji Dadjal (1941). Keduanya terbit sebelum perang, merujuk kepada periode sebelum Perang Pasifik ditabuh.
Penelitian ini merupakan penelitian sejarahsastra dengan pendekataan new historisism, pandangan yang tidak memisahkan karya sastra dengan pengarang dan zamannya. Menurut pandangan ini, fakta dan fiksi tidak terpisahkan, sastra dan sejarah telah lesap batas.Seperti yang dikatakan salah seorang penganjurnya, Louis A. Montrose, "membaca sastra sama dengan membaca sejarah, membaca sejarah sama dengan membaca sastra” (Melani Budianta 2006).Dalam perspektif demikian ini, karya sastra terikat-erat dengan pengarangnya. Pandangan-pandangan dalam karya sastra [roman], di antaranya, dianggap punya hubungan dengan pandanganpandangan penulisnya sendiri. Dengan begitu, artikel ini hendak mencari keterhubungan antara karya sastra dan pengarangnya dalam konteks ruang-waktu [sejarah].

\section{REALITAS-BIOGRAFIS PENGARANG}

Xarim tidak begitu dikenal dalam sejarah kusastraan Indonesia.Agak aneh memang, padahal 
jika dilihat karir kepengarangannya, dia telah melahirkan cukup banyak karya tulis bergenre fiksi. Selain dua roman yang dibahas artikel ini, ada lagi karya lain yang ditulisnya semisal Lagoe dan Njanjian(roman yang terbit tahun 1940) dan Ratna Kasihan Melati Deli (naskah tonil [sandiwara] yang terbit tahun 1932). Di samping karya fiksi, dia juga menulis karya kesejarahan di antara biografi Raja Saudi bertajuk $A b d u l$ Aziz Ibnoe Soe'oed: Pahlawan Tanah Arab yang diterbitkan tahun 1934 di Medan (Horton, 2012).

Tidak dikenal luas dalam sejarah kesusastraan, Xarim justru lebih dikenal sebagai salah seorang pemimpin komunis Sumatra yang cukup penting. Ia yang bernama asli Abdoe'l Karim Moehammad Soetan adalah "seorang Minangkabau yang tumbuh di Aceh dan Sumatra Timur," tulis Anthony Reid (2005) dalam An Indonesian Frontier: Acehnese and Other Histories of Sumatra. Menurut sumber lain, istrinyalah yang orang Minangkabau, bukan Xarim. "Seorang tokoh militan bernama Abdoel Xarim M.S., yang kawin dengan seorang wanita Padang...," demikian ditulis A.J. Piekaar(1977) dalamAtjeh en de oorlog met Japan. Sekalipun terdapat perbedaan mengenai dari mana Xarim berasal, tetapi tidak diragukan lagi bahwa dia merupakan aktivis penting komunis.Dia adalah seorang "the commander of the PKI in Sumatra”, tulis Takao Fusayama (2010) dalam A Japanese Memoir of Sumatra, 1945-1946: Love and Hatred in the Liberation War.Pada tahun 1924, dia menjadi pemimpin PKI di Langsa dan kemudian menjadi komisioner CC-PKI untuk Sumatra. "In 1924, Abdoe'lxarim became the leader of the Langsa PKI branch and then the CCPKI commissioner for Sumatra," begitu dikuatkan
William Bradley Horton(2012). Parada Harahap (1926), sejawatnya dalam pers pergerakan, dalam Dari Pantai ke Pantai jilid II, dengan agak hiperbolik mengebut Xarim sebagai “...seorang Communisten sedjati" (anggapan yang terbukti tidak sepenuhnya benar di kemudian hari).

Diketahui bahwa Xarim sesungguhnya bukanlah seorang yang sebagaimana digambarkan oleh Parada Harahap itu sebagai'komunis sejati'. Di tataran kaum komunis,Xarim digelari 'komunis non-politik' karena sikapnya yang cendrung borjuis. Ketika pemerintah kolonial (karena membengkaknya pengeluaran) memutuskan memulangkan tahanan politik yang 'tidak berbahaya' dari Digul pada 1932, Xarim berada dalam gelombang pertama yang dipulangkan. Selama di Digul, dia adalah seorang tahanan yang kooperatif, sehingga berada dalam daftar yang pertama kali dipulangkan. "As a cooperative prisoner "willing to work", he was among the first released and allowed to return home," tulis Horton. Ketika kemudian Jepang tiba, dia juga memilih bekerja sama dengan Jepang ketimbang melakukan politik non-kooperasi sebagaimana garis perjuangan yang dilakoni kaum komunis pada umumya pada periode itu. Pada 1956, dia keluar dari PKI, tulis Pramoedya Antara Toer. Tidak ada keterangan lebih lanjut untuk menjelaskan ini, tetapi besar kemungkinan kalau hal tersebut disebabkan karena dia telah sama sekali tidak cocok dengan garis ideologi PKI pada kurun tersebut.

Selain dikenal sebagai tokoh penting komunis, namun Xarim memiliki kedekatan yang nyaris intens dengan kaum modernis Islam. Horton (2012), misalnya, mengatakan 
bahwa Xarim telah lama berteman dengan Natar Zainuddin yang merupakan 'brother-in-law'-nya. Natar Zainuddin sendiri tidak hanya seorang partisan komunis yang penting tetapi juga adalah seorang reformis Islam pada sisi yang lain. Belum lagi, ketika diinternir di Digul, Horton menuliskan bahwa Xarim telah juga menyerap banyak sekali ide-ide kaum modernis Islam. Ini karena dia tinggal di kawasan Islamis dari Sumatra, yang sangat mungkin telah berkenalan dan telah familiar dengan ide-ide Haji Misbah mengenai penyatuan Islam dan komunisme. Di Sumatra ide-ide penyatuan itu telah pula disebarkan oleh Datuak Batuah dan Natar Zainuddin, dan telah memperoleh banyak pengikut dari kalangan Islam, hingga keduanya dibuang ke Digul.

Hanya saja, dalam artikelnya itu, Horton tidak menuliskan tentang kedekatan Xarim dengan pimpinan Muhammadiyah, sebuah organisasi kaum reformis Islam yang di Sumatra mula berkembang pada dua dekade awal abad ke20 (Hamka 1958; Deliar Noer 1996). Kedekatan ini mungkin saja telah semakin mengentalkan ide-ide kaum reformis Islam dalam kepala Xarim. Hamka, yang menjabat ketua Muhammadiyah di Medan, adalah sahabat karib Xarim. Xarim disinyalir pernah berkata kepada Hamka, sebagaimana ditulis Abdul Latip bin Talib (tt.) dalam Hamka, bahwa dia, Xarim itu, adalah "... antara sahabatmu yang akrab”. Xarim, yang menyebut Hamka sebagai Engku Haji "selalu menyokong Engku Haji pada setiap keadaan." Sekalipun kemudian keduanya terpisah jalan ketika zaman revolusi meledak, namun dapat dipastikan bahwa selama menjalin persahabatan mereka telah saling bertukar pendapat dengan intens dalam waktu yang cukup lama.

\section{PANDOE ANAK BOEANGAN: CITRA AMBIVALEN KAUM KOMUNIS}

\section{Pertama: Pertumbuhan Komunis di Sumatera}

Komunisme masuk ke Sumatera pada awal abad ke-20. Pertumbuhannya yang cepat berlangsung di Medan dan Sumatera Barat. Untuk Suamtera Barat, ide-ide kaum komunis disebarkan di lewat jasa Magas, seorang pemuda asli Sumatera Barat yang pernah lama tinggal di Jawa dan sempat lama bergaul dengan beberapa tokoh komunis di sana (Mestika Zed 2004: 4). Setelah diperkenalkan, komunisme kemudian berkembang dengan berbagai praksis. Tokoh-tokoh komunis mencobakan berbagai kemungkinan agar komunisme dapat diterima secara luas oleh orang Minangkabau, misalnya dengan cara mendekatkan komunis kepada Islam. Jika semula kehadirannya di Sumatera Barat hanya untuk menandingi Syarikat Islam yang telah lebih dulu ada, dua tahun setelah kehadirannya gerakan komunis mendapat tempat yang luas di tengah masyarakat Minangkabau. Apalagi sejak dipindahkannya pusat gerakan komunis dari Padang ke Padangpanjang, praktis, komunis Padangpanjang memainkan peran yang gemilang dalam menarik pengikut.

Haji Datoek Batoeah, seorang tokoh adat dan guru agama di Sumatera Thawalib, mencoba menggabungkan antara prinsip-prinsip komunisme dan Islam. Di tangan Batoeah, komunis terlihat lebih ramah di mata kaum muslim. Bersama Natar Zainuddin, mereka mencoba menggabungkan semangat jihad Islam dengan ideologi pembebasan kaum marxis. Islam dan komunis sama-sama gerakan revolusioner, begitu tesis yang dipakai Batoeah. Semangat anti pemerintah juga dipupuk 
terus-menerus dengan berbagai rapat akbar dan penyebaran tulisan-tulisan di surat kabar. Datoek Batoeah mendirikan surat kabar Pemandangan Islam, sementara Natar Zainuddin menerbitkan Djagodjago, kedua koran itu dengan gencar menerbitkan tulisan-tulisan yang keras membongkar kebobrokan penguasa kolonial Belanda (Kahin 2008: 127). Di tangan mereka, komunis tersiar demikian cepat di Sumatera Barat.

Di kalangan murid-murid Sumatera Thawalib (sebuah sekolah milik kaum modernis Islam yang terkenal), tempat Datoek Batoeh tercatat sebagai guru, gerakan komunis diterima, dalam catatan Hamka (1982: 143), selekas "rumah terbakar di musim panas". Apalagi, ketika itu hampir tidak ada gerakan radikal yang muncul pasca-dihancurkannya perlawanan rakyat dalam Pemberontakan Pajak pada kurang-lebih satu dasawarsa yang telah lewat. Gerakan komunis, catat Hamka, pada waktu itu diharapkan oleh orang Minangkabau akan dapat membangkitkan kembali semangat perlawanan terhadap pemerintah kolonial (Hamka 1982: 144).

Penyebaran gerakan komunis yang demikian pesat bukannya tanpa lawan. Penolakan yang keras muncul dari ulama pembaharu dari kalangan Sumatra Thawalib sendiri. Haji Abdul karim Amarullah, kepala sekolah itu, menjadi penentang paling keras terhadap penyebaran nilai-nilai komunis ke tengah masyarakat Minangkabau. Namun, koran-koran komunis dengan segera menghantam beliau dengan tidak kalah kerasnya. Haji Abdulkarim Amarullah, dikatakan dalam koran-koran komunis, menurut catatan Hamka, sebagai "pemeras rakyat, minta sedekah, menjual ayat untuk kepentingan diri sendiri”. Suara kaum komunis semakin tidak bisa dipepat, semakin waktu semakin lantang dan garang. Kelompok komunis bahkan sudah berani melakukan perlawanan terhadap pejabat-pejabat pemerintah setempat dengan cara menyindir (bahkan menghujat) dalam rapat-rapat akbar.

Namun, sikap keras itu punya konsekuensinya: pemerintah kolonial Belanda juga bertindak keras dan tidak kalah garang. Di ujung tahun 1923, rentetan penangkapan terhadap aktivis komunis pun dimulai di Sumatera Barat. Dunia Achirat, Kamis, 10 Juli 1924, melaporkan "telah ditangkap Nawawi Arief dan dipreventief di Penjara Padang". Penangkapan itu bersebab Nawawi berbicara memburuk-burukkan pemerintah di Kampung Alai (Padang). Nawawi adalah seorang komunis asal Minangkabau yang baru kembali dari Bandung. "Ja, sekarang ada zaman preventief!" tulis Dunia Achirat pada terbitan yang sama. Pada 7 Maret 1924, Magas Abdul Madjid, Voorzitter Serikat Rakyat, juga telah ditangkap dan dipenjarakan di Penjara Padang, atas tuduhan "telah melakoekan penghasoetan"ketika rapat umum "protest vergadering" di Padangpanjang beberapa waktu sebelumnya. Bersama Magas ditangkap dan dipenjarakan pula A. Wahab (Sekretaris Partai Komunis Afdeling Padang), Djalaludidin (Sekretaris Serikat Islam), dan M. K. A. Gafoer (Sekretaris Serikat Rakyat). Dunia Achirat sekali lagi melaporkan bahwa surat-surat dan buku-buku yang terdapat di kediaman orangorang tersebut disita pihak kepolisian pemerintah. Pada waktu yang bersamaan, ditangkap pula 3 orang serdadu Manado yang telah masuk komunis di Alang Lawas (Padang). Semua nama di atas dibui di Penjara Padang. 
Bukan hanya di Padang, penggeledahan dan penangkapan besar-besaran atas aktivis komunis juga terjadi di Koto Laweh, nagari asal Datoek Batoeah-di mana gerakan komunis tumbuh dengan subur. Pada tanggal 11 bulan Maret, Haji Datoek Batoeah, redaktur suratkabar Pemandangan Islam, ditangkap dan ditahan dalam bui. Bersama Batoeah, ditangkap dan dibui pula rekan seperjuangannya, Natar Zainuddin, redaktur suratkabar Djago Djago di Padangpanjang. Kedua orang ini, dilaporkan pada waktu itu, akan diinternir (dibuang), tetapi sementara menunggu datangnya besluit, mereka telah dipindahkan dari Penjara Padangpanjang ke Penjara Padang. Surat kabar Telegram melaporkan, dua orang redaktur dua suratkabar yang berbeda itu didakwa "membikin persekutuan akan mengatur pemberontakan di Padangpanjang". Nama-nama lain yang ditangkap di Koto Lawas bersama Datoek Batoeah adalah Datuk Indo Kayo, Mangkudun Sati, Djoeret, Ibrahim, Rajo dan Kayo, dan Baginto Tan Emas. Mereka semua ditangkap polisi intelijen yang dibantu militer yang secara khusus didatangkan dari Padang.

Tertangkapnya tokoh-tokoh komunis 'awal' tidak serta-merta memadamkan api gerakan komunis. Organisasi-organisasi sayap perkumpulan komunis seperti Serikat Rakyat, Serikat Tani, Serikat Tambang, Serikat Ibu, dan lain-lainnya, semakin tumbuh berkembang. Rapat-rapat akbar yang menyebarkan propagandapropaganda anti pemerintah disebarkan ke nagarinagari. Tidak mengherankan jika semakin hari semakin banyak orang yang menjadi anggota perkumpulan. Kritik-kritik tajam terhadap pemerintah diutarakan dalam pertemuanpertemuan perkumpulan itu. Kritik-kritik itu misalnya bersoal pembayaran belasting dan bersoal pengerukan 'gunung emas kita' di Sawahlunto oleh Belanda. Tentang yang disebutkan terakhir, propagandanya demikian gencar, terutama di suratkabar Suara Tambang, yang dengan giat menjadi corong suara para buruh tambang di Sawahlunto. Mari kita dengar nada keras salah satu cuplikan beritanya: “... tidakkah saudara mengetahui, hasilnya yang bermilyun-milyun diambil saja oleh kapitalis dan saudara kita yang sebelah sana umpamanya Silungkang, Padang Sibusuk, tidak mendapat sedikit juga hasil Sawah Lunto itu, jangankan mendapat hasil, sedangkan sawah yang sudah jadi dulu, sekarang tidak lagi, karena kekurangan air disebabkan tambang batubara itu.

Tidak ayal lagi, di tengah semakin memanasnya suasana politik, kaum komunis telah mulai berancang-ancang untuk sebuah pemberontakan besar. Namun, sebagaimana telah disinggung juga di awal, menjelang pemberontakan yang besar benar-benar terjadi, masih akan banyak penangkapan-penangkapan orang komunis yang terjadi disebabkan gerakan-gerakan kecil yang tidak terorganisir. Pandji Poestaka misalnya melaporan tentang seorang komunis yang tidak disebutkan namanya, membuat pabrik senjata di dalam hutan di daerah sekitar Padang Sibusuk dalam rangka menyiapkan sebuah revolusi berdarah. Tetapi, pada November 1926, polisi mencurigai orang itu karena dia terlalu banyak membeli batubara di Ombilin, yang memang digunakannya untuk keperluan pembuatan senjata.Polisi menangkapnya dan langsung membuinya.Banyak orang-orang yang terindikasi komunis ditangkap sepanjang tahun 1926 itu, beberapa bulan saja menjelang Pemberontakan Silungkang terjadi. Pada Agustus 
1926, menurut laporan suratkabar, Asisten Demang Sicincin dibunuh oleh "sekawanan kaoem kominis". Polisi kemudian menangkapi orang-orang komunis yang terkait pembunuhan itu.Pakiah Antok, yang diduga membunuh Asisten Demang Sicincin itu, ditangkap dan dipenjarakan di Fort de Kock. Sebelumnya, telah lebih dulu, ditangkap dan dibui 23 orang komunis lain yang dianggap terlibat pembunuhan tersebut, demikian dilaporkan Pandji Poestaka, 27 Agustus 1926.

Titik puncak ketidakpuasan kaum komunis terjadi pada akhir Desember 1926, dan memunculkan rencana gerakan pada awal Januari tahun 1927.Beberapa puluh orang berkumpul di sebuah rumah besar di Pasar Silungkanguntuk merencanakan sebuah pemberontakan. Seekor kerbau direbahkan dan dimasak untuk makan besar. Banyak orang yang hadir, tulis Mestika Zed, hingga melimpah keluar rumah. Besoknya, pemberontakan meletus. Beberapa orang pejabat pemerintah di Sawahlunto dan di Silungkang dibunuh, beberapa orang guru yang berafiliasi kepada pemerintah juga dibunuh, dan penjara Sungai Durian diserang. Pemberontakan juga diikuti di kota dan daerah lain di Sumatera Barat. Di Padang, berpusat di Pauh, juga meletus perlawanan yang serupa, meskipun tidak sebesar di Silungkang. Di Padangpanjang dan Fort de Kock, gerakan terburu diketahui mata-mata pemerintah sehingga tidak jadi meletus. Penguasa setempat dianggap berjasa karena dengan cepat dapat membaca situasi.

Secara umum, Pemberontakan Komunis 1927 itu mati dengan cepat sebelum sempat berkembang. Apalagi, tentara tambahan didatangkan pemerintah kolonial dari Batavia dan
Cimahi (sebanyak 11 brigade) di bawah pimpinan Mayor Rhemrev dan tiba di Padang pada bulan itu juga.Sejak Pemberontakan Komunis yang gagal itu, di Sumatera Barat penangkapan besar-besaran semakin marak terjadi. Suryadi menulis, di manamana terjadi penangkapan dan pengeksekusian para pemberontak. Dalam waktu singkat, 1100 orang ditangkap di seluruh pedalaman Minangkabau dan 150 lainnya ditangkap di Padang dan sekitarnya (Suryadi 2015).

Sementara tokoh utama pemberontak seperti Kaharudin Manggulung, M Yusuf, Sampono Kayo, Ibrahim Malawas digantung di Pasar Silungkang. Tokoh pemberontak lainnya seperti Sulaiman Labai langsung dibuang ke Ambarawa dan akhirnya meninggal di daerah itu. Empat orang tokoh pemberontak lainnya ditembak serdadu Belanda di Stasiun Silungkang. Hingga Februari 1927, dilaporkan Pandji Poestaka, "Kepala-kepala kominis di Soematera Barat hamipir semoenya soedah dapat ditangkap atau diboenoeh, misalnja: Si Patai (ditembak mati), Ngadimin (ditembak mati), Soeman (ditangkap), Hadji Iman Samad (ditangkap), Nain (ditangkap), dan Hadji Dagam (ditangkap).Tokoh-tokoh pemberontak yang mendapat hukuman dua tahun ke bawah dimasukkan ke Penjara Sawahlunto. "Sekalian orang peroesoeh jang soedah ditangkap dikoeroeng dalam boei Sawah Loento semuanja ada 900 orang," demikian diberitakan Pandji Pustaka, 18 Januari 1927, kurang dari tiga minggu setelah pemberontakan meletus. Sementara mereka yang tidak tertampung di penjara tersebut dikirim ke Penjara Padang bersama pemberontakpemberontak lain yang ditangkap di Pauh dan Koto Tangah, dan beberapa yang lain yang ditangkap di Padangpanjang. 
Penangkapan orang-orang komunis itu tidak hanya terjadi di Sumatera Barat saja, tetapi juga meluas hampir ke seluruh Sumatera, bahkan Hindia Belanda. Selain dipenjarakan, banyak dari para tahanan komunis itu kemudian dibuang ke Boven Digul, kamp yang dibangun tidak berselang lama setelah pemberontakan. Menurut Chalid Salim (1989: 283), hampir 60 persen penghuni kamp konsentrasi di Tanah Papua itu adalah orang-orang komunis.Salah seorang di antaranya yang dibuang ke sana adalah Abdoe'lxarim M.S. yang ketika ditangkap menjabat sebagai komisioner CC-PKI untuk Sumatra.

\section{Kedua: Citra kaum komunis dalam pandangan Xarim}

Xarim menulis sebuah romanyang mengisahkan tentang kaum komunis pada masa pembuangan di Boven Digul. Bagaimana kaum komunis direpresentasikan dalam romannya itu?

Pandoe Anak Boeangan karya Xarim. aslinya terbit dalam seri roman Aneka yang muncul di Medan pada tahun 1933. Tetapi belakangan roma ini menjadi salah satu di antara 5 roman yang bercerita tentang kehidupan kaum digulis yang termaktub dalam buku Cerita dari Digul (2001) yang disunting Pramoedya Ananta Toer. Pandoe Anak Boeangan adalah sebuah kisah asmara seorang digulis di belantara Digul yang penuh malaria. Alih-alih berbicara tentang perjuangan mewujudkan ide-ide besar serupa sosialismekomunisme, roman ini justru berbicara tentang sengkarut cinta antara insan-manusia.

Pandoe, tokoh utama roman ini, pada mulanya adalah seorang pegawai pemerintah yang mapan, berasal dari keluarga biasa yang mendapat jodoh anak seorang juru tulis yang berada dan cukup berpengaruh. Sejak itu karirnya melonjak. Tetapi, di tengah perjalanan karir yang bagus, cerita menelikung: Pandoe bercerai dengan istrinya karena berbagai ketidakcocokkan. Melarikan diri dari kesedihan hati akibat kegagalan berumah-tangga, Pandoe pergi ke Semarang. Di 'kota merah' itu dia terbawa arus Serikat Islam yang sedang bergejolak akibat semakin dominannya unsur komunis. Pandoe bertemu dengan kawan sesama aktivis bernama Erni dan keduanya sepakat menjalin cinta dan hidup berumah tangga. Tapi Pandoe dikecewakan lagi ketika Erni menolak mengikutinya ke Digul ketika pemerintah kolonial membuangnya.

Di tanah pembuangan itu, Pandoe memilih menyendiri, tidak terlibat dalam hubungan sosial apa pun. Tapi entah kenapa, cerita lagi-lagi menikung: Pandoe terlibat upaya melarikan diri. Bersama lima orang sesama digulis, dia kabur dari sana. Tetapi, dalam pelarian, malang menimpa Pandoe, kakinya terkena jerat babi yang dipasang Kaya-kaya penyebutan untuk orang Papua ketika itu. Orang-orang di luar Papua menganggap orang Papua primitif, bahkan ada yang kanibal. Tapi bukannya hendak dimakan, Pandoe malah diselamatkan suku tersebut. Hingga kemudian dia dinikahkan dengan anak gadis Kayakaya.

Tetapi, razia polisi Belanda berhasil menangkap Pandoe dan mengembalikannya ke kamp. Sekembalinya ke kamp, Pandoe tidak mau mengaku kepada teman-temannya kalau dia telah menikah dengan perempuan Kayakaya. Dia merasa malu mengakui kenyataan tersebut.

Pada titik ini, terlihat bagaimana citra kaum komunis yang hendak digambarkan Xarim. Pandoe adalah tokoh komunis yang ambivalen: 
menginginkan kesamaan kelas masyarakat tetapi juga membedakan ras manusia. Mencita-citakan masyarakat di mana ketidaksetaraan kelas terhapus, tetapi juga pada saat yang sama mengamini ketidaksetaraan bangsa. Dia dibuang karena berjuang untuk Sosialisme-Komunisme yang Agung, tetapi ketika berhadapan dengan suku Kayakaya-Papua, dia malam memandang mereka sebagai bangsa yang masihlah sangat rendah. Oleh sebab itu pula, dia malu mengakui istrinya itu dan bahkan juga cabang bayi hasil perkawinan mereka.

\section{HADJI DADJAL: GEMA SUARA KAUM PEMBAHARU ISLAM}

\section{Pertama: Gerakan Pembaharuan Islam di Sumatera}

Sejak Jamaludin Al-Afghani, Muhammad Abduh, dan Kairuddin Al-Tunisi mengguncang dunia Islam dengan pemikiran-pemikiran pembaruannya.Di berbagai belahan dunia Islam kemudian, para pembaharu berlahiran, menebarkan semangat pembaharuan. Mereka "mencoba menyesuaikan kesadaran keagamaan dengan kenyataan hidup yang dialami” umat muslim hari ini.

Di Sumatera, gerakan pembaharuan berpusat di Minangkabau.Bagi masyarakat Minangkabau, Islam merupakan keyakinan keagamaan yang merembes masuk ke dalam pengetahuan, perilaku dan makna budaya. Menjadi muslim adalah orientasi terdalam dari identitas Minangkabau (Lucy A Whalley 1996: 207). Masyarakat Minangkabau taat kepada Islam dan dalam waktu yang sama juga pengikut adat yang kuat (Kato 1978; Hadler 2008). Upaya memadukan keduanya berlangsung nyaris sepanjang waktu.Sejak ketika Islam naik ke dataran tinggi Minangkabau, upaya menyinergikan kedua praksis tersebut masih terus dilakukan. Surau Tuanku nan Tuo di Cangkiang pada akhir abad kedelapan belas misalanya memainkan perannya sebagai penyeimbang dua kekuatan yang mulai menampakkan tanda-tanda perseteruan di tengah zaman: praksis Islam yang mulai menampakkan kekuatan gerakannya dan praksis tradisi yang mulai terengah-engah meniti jembatan zaman (Dobbin 1983).

Namun, pada periode Padri, sejak akhir abad ke-18 hingga paro pertama abad ke-19, upaya ini berlangsung keras.Pada kurun ini, corak Islam menjadi sumber konflik yang serius. Ulamaulama yang baru pulang dari Timur Tengah mencoba melancarkan gerakan puritan yang keras berhadapan dengan pengikut tradisi yang juga merespon gerakan itu dengan keras (Radjab 1950:12).Di sisi yang lain, upaya yang berdarahdarah ini sesungguhnya juga dapat dikatakan sebagai upaya intergral dua praksis; berakhirnya periode Padri dapat memungkinkan harmonisasi dan integrasi Islam dan tradisi itu kembali. Sekalipun, Islam tetap menjadi basis perdebatan pada abad kemudian yaitu pada sepanjang abad kedua puluh. Pada kurun ini, persoalan keislaman dalam masyarakat Minangkabau menjadi semakin kompleks ketika praksis baru muncul: Barat. Pada paruh terakhir abad ke-19 dan paruh pertama abad ke-20, upaya integralitas itu tidak hanya melibatkan Islam dan tradisi, tetapi juga telah melibatkan suatu gejala baru yang bernama modernisme (Abdullah 1971).

Pengaruh keberadaan Belanda di Sumatera memunculkan dampak yang penting pula terhadap cita rasa keberagamaan di daerah ini. Sebagaimana telah disinggung sebelumnya, bahwa menjelang 
berakhirnya abad ke-19, pengaruh politik dan ekonomi kapitalis Belanda dan merembesnya gagasan-gagasan baru di Singapura, Makkah, dan Kairo melahirkan perdebatan hangat di kalangan kaum muslim. Beberapa kelompok Kaum Muda (Graves 1981: 9) memusatkan perhatian pada modernisasi hukum adat selaras denga polapola Barat dan sekuler. Kelompok Pemuda Melayu (1906) Perkumpulan Usaha (1912) dan Pemuda Sumatera (1918) didirikan untuk memperkenalkan sistem pendidikan modern dan untuk memasukkan gagasan Barat ke dalam hukum adat lama.Beberapa kelompok pemuda lainnya berorientasi kepada reformisme Islam. Sjekh Ahmad Khatib (1855-1916) yang belajar di Makkah, telah mengenal gagasan pemikiran Muhammad Abduh, setelah kepulangannya ia tampil sebagai generasi baru pemuda Sumatera dan ulama Melayu yang akhirnya mendirikan beberapa sekolah baru, penerbitan, dan gerakan dakwah Islam (Lapidus 1999: 322).

Syaikh Muhammad Thahir (1867-1957) juga belajar di Makkah, menyerap gagasan Muhammad Abduh, dan mendirikan surat kabar al-Imam di Singapura. Al-Imam berusaha menyadarkan umat Muslim akan pentingnya pendidikan. Ia mengajarkan bahwanya kemunduran Islam disebabkan pengabaian Syari'at Islam dan bahwasanya kepatuhan terhadap Qur'an dan hadits pasti akan meningkatkan derajat kehidupan individu Muslim dan akan membantu melahirkan renaissance di dalam komunitas muslim. Al-Imam menekankan pentingnya penggunaan akal dalam masalah agama dan menentang praktik dan keyakinan adat.Ia juga menghadirkan ke tengah masyarakat perdebatan sekitar permasalahan agama seperti apakah bacaan talqin harus dibaca di atas makam, manakah cara yang benar mengenai niat, apakah membacanya dengan nyaring atau secara lemah, dan bagaimana hukum menabung di bank dan usaha bersama. (Lapidus 1999: 332).

Sebagai konsekuensi dari adanya perbedaan paham keagamaan antara kaum modernis dengan kaum tradisionalis inilah, maka pertentangan pun tidak dapat dihindarkan.Kendati secara umum pertentangan tersebut sesungguhnya tidak beranjak dari persoalan keagamaan yang sifatnya furu'iyah belaka, yang sejak awal memang telah menjadi sumber perdebatan di mana pun Islam berkembang. Dalam konteks Sumatera, ketegangan yang dihadapi oleh kaum Islam tradisionalis sesungguhnya lebih kompleks lagi, karena mereka tidak hanya harus menerima 'serangan' dari kaum modernis, melainkan pada saat yang sama juga dihadapkan pada pertentangan antar-sesama kelompok Islam tradsionalis sendiri, yakni antara penganut tarekat Syatariyyah dengan tarekat Naqsybandiyyah. Tarekat yang disebut terahir misalnya menuduh pada penganut tarekat Sattariyyah sebagai sesat (heretic), karena dianggap mengajarkan doktrin martabat tujuh dan waudat al-wujud (kesatuan wujud) (Fathurahman 2004: 4).Xarim, dalam konteks ini, telah berkenalan dengan beberapa tokoh modernis Islam Sumatera (seperti Hamka dan Natar Zainuddin) yang turut pula kemudian menggemakan pemikiranpemikiran modernis itu dalam romannya.

\section{Kedua: Ide-ide reformis Islam dalam penggambaran Xarim}

William Bradley Horton(2012), yang menulis artikel berjudul "The Political Work of Abdoe'lxarim M.S. in Colonial and Japanese Occupied Indonesia (1930s-1940s)”, menyebut 
roman ini menggemakan kritik sosial yang revolusioner untuk zamannya. Terbit tahun 1941 di Medan dalam seri-roman Loekisan Pudjangga, roman ini terasa sebagai sebuah kritik-parodik, gaya penceritaannya ringan dan kocak, dengan tokoh utamanya yang karikatural. Roman ini sendiri berbicara tentang seorang pedagang cendol kaki lima bernama Oemar. Orang-orang di sekitarnya menggelarinya Dadjal karena sikap beragamanya yang 'lain'.

Xarim, tentang tokoh romannya itu, menggambarkan:

"Seringkali orang berbantah dengan dia lantaran membitjarakan hoekoem-hoekoem, oempama bersoetji, sembahjang, membatja do'a, dan lain-lain, tetapi dia tinggal kepala batoe dan ta' hendak mengalah".

Akibat 'kebertikaiannya' itu, orang-orang menyisihkannya, dan menggelarinya Dadjal. Xarim menulis:

"Oleh sebab fahamnja jang sangat menikai maka selaloe ia disisih orang tapi ia sendiripoen ingin menjisih. Orang jang tinggal sekampoeng dengan dia heran memikirkan mengapa ia bertabi'at demikian, tapi ia ta' hendak menghiraukan pikiran orang."

Xarim tidak menjelaskan dari mana Oemar berasal. Mula-mula Oemar berdagang cendol yang dipikul dari lorong ke lorong di jalan-jalan di Singapura. Dia melakoni pekerjaannya itu selama tujuh tahun sambil terus menyisihkan keuntungan sedikit demi sedikit. Setelah tujuh tahun itu, dia membuka seluruh isi tabungannya lalu pergi ke Mekkah. Kita akan menyangka dia pergi ke Mekkah untuk naik haji belaka, tetapi roman ini menciptakan tikungannya yang menggelitik: Si Dadjal pergi ke Mekkah untuk menjual cendol juga, berpikir bahwa tanah Arab yang panas akan membuat cendolnya laku lebih laku ketimbang di tanah Melayu apalagi ketika musim haji tiba. "Beriboe-riboe bangsa saja jang kepanasan disini, maka harapan akan mendapat oentoeng dari tjendol ada besar sekali," demikain Oemar, "Saja memang bermaksoed kemari akan naik hadji, akan tetapi tidak ada larangan dalam hoekoem akan mentjahari rezeki jang halal."

Hadji Dadjal melancarkan kritik yang keras atas praktik-praktik beragama kaum tradisional dunia Melayu pada zamannya. Ada beberapa kritik yang diusung roman ini terutama terhadap praktik-praktik beragama jemaah haji di Mekkah. Di antaranya adalah dia menolak ziarah sebagai bagian dari praktik haji. Sebab ketika itu, menurut roman ini, trip ziarah "ke koeboeran 'oelama'oelama dan wali jg besar-besar" telah menjadi 'seolah-olah' praktik wajib dalam haji. Oemar menolak praktik itu dan menganggapnya hanya "oendjoekan daripada orang jang mengatakan dirinja alim", dengan tujuan tiada lain "hanja satoe daja oepaja boeat memaksa orang jang sampai kemari, soepaja keloear wangnja, lain tiada!" [Oemar sebenarnya tidak melarang seluruh bentuk praktik ziarah, sebab dia juga turut berziarah tetapi hanya "kemakam Rasoel Allah, lain tidak"].

Oemar juga mencerca praktik-praktik beragama orang Melayu di Mekkah ketika musim haji di mana banyak di antara mereka yang mengultuskan seorang Habib sebagai 'keturunan Nabi' sehingga mereka mengambil berkat padanya. Dia tidak hanya mencerca kebodohan jemaah Melayu, tetapi juga mencerca 'Habib-habib' yang dianggapnya telah menipu orang-orang yang fanatik terhadapnya untuk mendapatkan uang. Oemar mencecar seorang Habib yang berusaha memberinya berkat lalu kemudian meminta sedekah: "Fasal apa akoe akan mentjioem 
tanganmoe? Akan mengambil berkat? Berkat apa, kau sendiri- poen tidak mendapat berkat, dari mana kau akan memberi berkat? Kau toch boekan Toehan, jang berhak memberi berkat?”

Sehubungan dengan itu, Oemar lebih lanjut juga menolak kultus Arab sebagai yang paling shahih menerjemahkan Islam. Ketika Oemar dicerca pertanyaan oleh seorang kadi di Mekkah dalam sebuah perdebatan di pengadilan yang mencoba mengadilinya, sang kadi berkata:

"Apa kamoe bilang? Kamoe lebih tahoe dari kami orang 'Arab tentang agama Islam? Agama Islam datang dari 'Arab dan jang mengislamkan orang Djawi, poen orang 'Arab. Sekarang kamoe lebih tahoe dari orang 'Arab?" Oemar membantah kadi tersebut dengan berkata: "Betoel agama Islam datang dari 'Arab dan jang mengislamkan orang Djawipoen orang 'Arab djoega, tetapi boekan orang 'Arab jang sekarang, melainkan jang dahoeloe, dan sekarang mereka ta' ada lagi.”

Oemar, dalam roman ini, kemudian juga mengkritik prilaku orang-orang yang pergi berhaji untuk 'pakaian' dan 'gelar'. Oemar mengata-ngatai mereka dengan marah.

Xarim menulis:

\footnotetext{
"Kamoe semoea tiada maoe memakai pikiranmoe ... Kamoe beli serban, djoebah, gamis, dan lain-lain jang mahal-mahal dan kamoe toekar nama dengan nama baroe, sedang nama jang diberikan oleh ajahmoe kamoe boeang semoea, dan boeat ganti nama itoe kamoe haroes membajar kepada orang 'Arab itoe. Alangkah bodohnja kamoe lagi!"
}

Oemar juga menolak praktik memberi "fidiah sembahjang dan poeasa, serta sedekah dan kendoeri” bagi yang meninggal di tanah sucisuatu praktik yang juga umum dilakukan ketika itu dan seolah-olah telah jadi wajib dalam praktik haji. Bagi Oemar, praktik itu hanyalah praktik kapital belaka, "hanja soeatoe 'akal oentoek menarik wang dari kantoeng orang, atau soeatoe 'akal oentoek menarik keoentoengan atas nama
Toehan...". Kata Oemar lagi: "Atoeran fidiah itoe adalah salah satoe djalan jang memberikan keoen toengan pada lebai-lebai atau kiaji-kijai....”.

\section{KESIMPULAN}

Dua roman yang ditelaah memperlihatkan keterkaitannya dengan kondisi lingkungan sosial dan realitas-biografis pengarangnya.Roman pertama, Pandoe Anak Boeangan, memperlihatkan kaum komunis dalam representasi yang ambivalen. Dalam penggambaran Xarim, kaum komunis berjuang untuk kesetaraan kelas, tetapi ketika berhadapan dengan masyarakat 'sederhana' Papua, ide-ide itu sama sekali terpental. Tokoh dalam roman Xarimitu menginginkan kesamaan kelas masyarakat tetapi juga membedakan ras manusia. Mencita-citakan masyarakat di mana ketidaksetaraan kelas terhapus, tetapi juga pada saat yang sama mengamini ketidaksetaraan bangsa.

Sementara roman Hadji Dadjal adalah sebuah penolakan yang keras atas kultus dan taqlid kepara sayyid, sjekh, habib, dan para alim lainnya dari kalangan tradisional; roman ini menganjurkan penggunaan akal dalam beragama dengan menjauhkan diri dari kultus terhadap alim-alim/garis keturunan/tempattempat tertentu dan praktik-praktik agama yang tidak memiliki dasar akal-sehat. Jika dtelisik kesamaan nadanya terdengar bahwa romanini menggemakan suara-suara kaum modernis Islam pada dekade-dekade awal abad ke-20 yang hendak menghancurkan kebekuan pikiran/kejumudan di tengah umat dan penghambaan kepada kultulkultus guru/ulama. Dapat dikatakan bahwa suara kaum reformis Islam digemakan kembali oleh Xarim dalam romannya ini. 
Kedua roman ini berkait dengan kondisi sosial zamannya, di mana gerakan komunis sedang berlangsung (dan mendapat tantangan hebat dari pemerintah kolonial) dan pembaharuan Islam sedang mendapat momentum untuk berkembang seiring semakin banyak kaum cerdik-cendikia yang muncul. Dan juga, kedua roman ini punya keterkaitan dengan riwayat pengarangnya sendiri. Xarim merupakan aktivis komunis sebelum dan setelah perang,bahkan menduduki posisi penting dalam partai, tetapi tidak dapat dianggap 'sedjati' karena bersikap lebih oportunistis dan memilih 'menyimpang' dari partai pada periode akhir. Di sisi lain, dia juga berhubungan dekat [nyaris erat] dengan kaum modernis Islam untuk menyerap banyak ide-ide pembaruan yang mereka tawarkan. Kedua hal ini kemudian tercermin dalam roman yang ditulisnya. Kenyataankenyataan di atas ini, menjadi dasar yang logis, mengapa pandangan Xarim terhadap kaum komunis tampak ambivalen, sementara di sisi lain kedekatannya dengan kalangan Islammodernisdiduga kuat telah menjadi dasar yang masuk akal jika kemudian romannya mengandung pesan-pesan pembaharuan Islam.

\section{DAFTAR PUSTAKA}

A Whalley, Lucy. (1996). "Meletakkan Islam ke Dalam Praktik: Perkembangan Islam Dalam Perspektif Gender Minangkabau” dalam Mark R. Woodward (editor), Jalan Baru Islam: Memetakan Paradigma Mutakhir Islam Indonesia. Bandung: Mizan.

Ananta Toer, Pramoedya. (2001). Cerita dari Digul. Jakarta: Gramedia.
Bradley Horton, William. (2012). "The Political Work of Abdoe'lxarim M.S. in Colonial and Japanese Occupied Indonesia (1930s-1940s)". Waseda Studies in Social Science, Vol. 12, No. 3.

Budianta, Melani. (2006). "Budaya, Sejarah \& Pasar: New Historisisme dalam Perkembangan Kritik Sastra”. Jurnal Susastra, Vol 2, No 3.

Dobbin, Christine. (1983). Islamic revivalism in a changing peasant economy: Central Sumatra 1784-1847. London: Curzon Press.

Fusayama, Takao. (2010). A Japanese Memoir of Sumatra, 1945-1946: Love and Hatred in the Liberation War. Jakarta: Equinox.

Graves, Elizabeth E. (1981). The Minangkabau response to Dutch colonial rule in the Nineteenth century. Monograph Series, Publication No.60. New York: Cornell Modern Indonesia Project.

Hamka. (1982). Ayahku:Riwayat Hidup Dr. Haji Abdulkarim Amarullah dan Perjuangan Kaum Agama di Sumatera Barat. Jakarta: Umminda.

Harahap, Parada. (1926). Dari Pantai ke Pantai Jilid II: Perdjalanan ke-Soematra. Weltevreden: Bintang Hindia.

Hardler, Jeffrey. (2008). Muslims and Matriarchs: Cultural resilience in Indonesia through jihad and colonialism. Ithaca and London: Cornell University Press.

Kahin, Audrey. (2008). Dari Pemberontakan ke Integrasi. Jakarta: Obor.

Lapidus, Ira. M. (1999). Sejarah Sosial Ummat Islam. Jakarta: PT. Raja Grafindo Persada. 
Latip, Abdul bin Talib. (tt). Hamka: Ulama, Pemimpin, Sasterawan. Kuala Lumpur: PTS Publication.

M.S., Abdoe'lxarim. (1933). Pandoe Anak Boeangan. Medan: Uitgevers Genootschap 'Aneka'.

M.S., Abdoe'lxarim. (1941). Hadji Dadjal. Loekisan Poedjangga th. III, no. Medan: Tjerdas.

Noer, Deliar. (1996). Gerakan Moderen Islam di Indonesia, 1900-1942. Jakarta: LP3ES.

Piekaar, A.J. (977). Aceh dan Peperangan dengan Jepang. Banda Aceh: Pusat Dokumentasi dan Informasi Aceh.

Reid, Anthony. (2005). An Indonesian Frontier: Acehnese and Other Histories of Sumatra. Singapura: Singapore University Press.
Suryadi. (2015). "Orang Komunis membuat senjata dalam hutan", Padang Ekspres, 22 November.

Suryadi. (2015). "Penyelidikan pembunuhan Asisten Demang Sicincin". Padang Ekspres, 8 November.

Suryadi. (2015). "Para pentolan komunis berhasil dilumpuhkan”. Padang Ekspres, 27 September.

Tamin, Djamaluddin. (1957). Sedjarah-P.K.I. (Partai Komunis Indonesia). Jakarta: Pustaka Murba.

Zed, Mestika. (2004). Pemberontakan Komunis Silungkang 1927. Jogjakarta: Syarikat Indonesia. 
